\title{
Profil Sensori Sediaan Pemanis dengan Metode Rate-All-That-Apply (RATA)
}

\section{Sensory Profile of Table-Top Sweeteners by Rate-All-That-Apply (RATA) Method}

\author{
Dede Robiatul Adawiyah $^{1,2)^{*}}$, Olivia Mellyana Tjiptoputri ${ }^{1)}$ Lince $^{3)}$ \\ 1) Departemen Ilmu dan Teknologi Pangan, Fakultas Teknologi Pertanian, Institut Pertanian Bogor, Bogor \\ ${ }^{2)}$ South East Asian Food and Agricultural Science and Technology Center, Institut Pertanian Bogor, Bogor \\ ${ }^{3)}$ PT. Nutrifood Indonesia, Bogor
}

\begin{abstract}
Sweetener is food additive consisting of natural sweetener and artificial sweetener which give sweet sensation to food products. Table-top sweeteners are sought due to its advantages in comparison to sugar, which is giving off sweet sensation in food with no or low calorie. This is proven useful for people who suffer from illnesses, such as diabetes mellitus, obesity, and sensitive tooth. This need should be supported by development of table-top sweeteners to satisfy consumer preferences. Rate-All-That-Apply (RATA) is a consumer based test developed from Check-All-That-Apply (CATA). The objective of this research is to study sensory profiles of various table-top sweeteners based on diabetic and non-diabetic consumer and its intensity, as well as identifying attributes which determines consumer preference. There were six table-top sweeteners used in this study with three group of panelists based on their medical history. The research result revealed that sweetener A was identic to the attribute cooling, sweet aftertaste, sweet, body thickness, licorice, and mouth drying. Sweetener $C$ and $F$ were identic to the attribute metallic aftertaste, bitter aftertaste, bitter, and metallic. Diabetics give the most hedonic score above the average value to Sweetener $A, B$, and $D$. Non-diabetics with a heredity of diabetes give the most hedonic score above the average value to Sweetener B. Non-diabetics without a heredity of diabetes give the most hedonic score above the average value to Sweetener D and E. Generally, consumer could not identify attributes which determines their preference, however they could define unwanted attributes in table-top sweeteners, which are bitter, bitter aftertaste, metallic, metallic aftertaste, and mouth drying.
\end{abstract}

Keywords: Check-All-That-Apply (CATA), consumer acceptance, diabetes, hedonic

\begin{abstract}
Abstrak. Pemanis merupakan bahan tambahan pangan berupa pemanis alami dan pemanis buatan yang memberikan rasa manis pada produk pangan. Sediaan pemanis semakin dicari dan digunakan karena memiliki beberapa keunggulan dibanding dengan gula, yaitu dapat memberikan rasa manis pada produk pangan dengan tidak atau sedikit sekali menambah kalori sehingga dapat digunakan untuk penderita diabetes mellitus, obesitas, dan gigi sensitif. Kebutuhan ini perlu didukung dengan pengembangan sediaan pemanis yang sesuai dengan permintaan pasar. Rate-All-That-Apply (RATA) merupakan uji konsumen yang dikembangkan dari metode Check-All-That-Apply (CATA) untuk menghilangkan kebutuhan melatih panelis. Tujuan penelitian ini adalah mempelajari profil sensori sediaan pemanis berdasarkan persepsi panelis diabetes dan non-diabetes dengan metode Rate-All-That-Apply (RATA), serta mengidentifikasi atribut yang menjadi penentu kesukaan konsumen pada sediaan pemanis. Terdapat enam sediaan pemanis komersial yang diuji dengan tiga golongan panelis sesuai dengan kriteria riwayat kesehatannya. Sediaan pemanis A identik dengan atribut cooling, sweet aftertaste, sweet, body thickness, licorice, dan mouth drying. Sediaan pemanis $\mathrm{C}$ dan $\mathrm{F}$ identik dengan atribut metallic aftertaste, bitter aftertaste, bitter, dan metallic. Panelis diabetes memberikan nilai kesukaan di atas rata-rata terbanyak pada sediaan pemanis A, B, dan D. Panelis non-diabetes dengan riwayat keturunan diabetes memberikan nilai kesukaan di atas ratarata terbanyak pada sediaan pemanis B. Panelis non-diabetes tanpa riwayat keturunan diabetes memberikan nilai kesukaan di atas rata-rata terbanyak pada sediaan pemanis D dan E. Secara keseluruhan, konsumen belum bisa mendefinisikan atribut yang disukai, namun sudah dapat menentukan atribut yang tidak diinginkan dalam sediaan pemanis, yaitu bitter, bitter aftertaste, metallic, metallic aftertaste, dan mouth drying.
\end{abstract}

Kata Kunci: Check-All-That-Apply (CATA), diabetes, penerimaan konsumen, uji hedonik

Aplikasi Praktis: Informasi yang dihasilkan dari penelitian ini menjadi informasi yang berguna bagi industri sediaan pemanis agar dapat membuat sediaan pemanis yang sesuai dengan preferensi konsumen. Metode yang digunakan merupakan metode yang lebih praktis digunakan dan dapat diaplikasikan di industri pangan yang ingin melakukan identifikasi profil sensori produk pangan menggunakan panel tidak terlatih atau panel konsumen. 


\section{PENDAHULUAN}

Pemanis (sweetener) merupakan bahan tambahan pangan berupa pemanis alami dan pemanis buatan yang memberikan rasa manis pada produk pangan (Perka BPOM 2014). Pemanis alami adalah pemanis yang dapat ditemukan dalam bahan alam. Contohnya manitol, sorbitol, dan glikosida steviol. Pemanis buatan adalah pemanis yang diproses secara kimiawi dan senyawa tersebut tidak terdapat di alam, seperti asesulfam-K, aspartam, dan siklamat (Menteri Kesehatan Republik Indonesia 2012).

Sejalan dengan berkembangnya industri pangan, bahan pemanis semakin dicari dan digunakan. Hal ini ditunjukkan dengan penggunaan pemanis yang mayoritas didominasi oleh industri pangan dengan sebaran 59\% digunakan untuk food ingredient, 25\% untuk non-food ingredient, $14 \%$ untuk table top, dan $2 \%$ untuk dietary supplement (AMI Bussiness Consulting 2001). Kecenderungan ini terjadi karena pemanis dapat memberikan rasa manis pada produk pangan dengan tidak atau sedikit sekali menambah nilai gizi/kalori. Hal ini membuat pemanis memiliki keunggulan dibanding gula, yaitu dapat digunakan untuk penderita diabetes mellitus, obesitas, dan gigi sensitif yang memberikan rasa manis tanpa memberikan resiko terhadap memburuknya penyakit. Selain, itu pemanis dapat memberikan sensasi manis yang mencapai 200-600 kali dari gula, sehingga sering disebut pemanis intensitas tinggi (high intensity sweeteners) dan relatif lebih murah dibanding gula, sehingga dapat menekan biaya produksi (Deis 2006). Menurut LMC International and The NutraSweet Company (2010), pasar pemanis secara global mencapai 1.2 milliar Dolar US.

Sediaan pemanis (table top sweetener) merupakan pemanis dalam bentuk granul, serbuk, tablet, atau cair yang siap dikonsumsi sebagai produk akhir yang dikemas dalam kemasan sekali pakai (Perka BPOM 2014). Sediaan pemanis merupakan alternatif untuk memberikan rasa manis untuk penderita diabetes. Target konsumen dari sediaan pemanis dapat dibagi menjadi dua golongan, yaitu penderita diabetes dan bukan penderita diabetes. Persepsi rasa antara kedua golongan ini memiliki perbedaan karena kondisi kesehatan tersebut. Penderita diabetes memiliki sensitivitas lebih rendah terhadap rasa manis dibandingkan non- diabetes. Hal ini ditunjukkan dengan ambang pengenalan konsumen diabetes yang lebih tinggi secara signifikan dibandingkan konsumen non-diabetes. Selain itu, perbedaan sensitivitas ini juga terlihat pada panelis yang mempunyai kecenderungan diabetes dari riwayat keturunan, walaupun tidak signifikan (Wasalathanthri $e t$ al. 2014).

Tingginya penggunaan pemanis di dunia memerlukan pengembangan pemanis yang sesuai dengan permintaan pasar terutama untuk mendapatkan pemanis dengan profil rasa manis yang menyerupai gula dengan tidak atau sedikit sekali menambah nilai gizi/kalori. Salah satu perangkat dari pengembangan produk yang memiliki peran penting adalah evaluasi sensori. Salah satu teknik evaluasi sensori yang banyak digunakan adalah sensory profiling yang digunakan untuk mendapatkan profil sensori produk dengan lengkap dan detail. Hal ini penting untuk pengembangan produk karena dapat digunakan untuk membandingkan perbedaan atribut sensori antar produk yang mirip (Lawless dan Heymann 2010). Teknik sensory profiling dapat dikategorikan dalam dua pendekatan, yaitu pendekatan berbasis produk dan pendekatan berbasis konsumen.

Teknik sensory profiling berbasis produk dilakukan dengan menganalisis produk secara objektif dengan asumsi bahwa panelis memiliki persepsi yang sama. Hal ini dilihat dari kinerja panelis yang akurat dan konsisten dengan kemampuan diskriminasi tinggi karena sudah melewati proses pelatihan (Wasink 2013). Hasil dari uji ini dapat diandalkan dan memberikan profil sensori produk yang komprehensif. Namun, pendekatan ini memiliki kelemahan di mana aplikasinya membutuhkan waktu yang lama dan biaya yang tinggi, karena perlu melatih panelis secara terus-menerus agar hasilnya baik. Oleh karena itu, teknik sensory profiling berbasis konsumen mulai banyak dipakai sebagai alternatif untuk menghilangkan kebutuhan melatih panelis dan mendapatkan umpan balik dari konsumen secara langsung (Ares et al. 2011). Kinerja diskriminasi konsumen (panelis tidak terlatih) rendah, sehingga memerlukan panelis dalam jumlah banyak agar meningkatkan realibilitas uji. Pada kondisi nyata, konsumen mendapatkan pengaruh di luar karakteristik produk untuk memproses atribut sensori yang mungkin tidak diperhitungkan oleh panelis terlatih (Wansink 2003). Oleh karena itu, umpan balik konsumen sangat penting dalam mendeskripsikan produk. Contoh teknik sensory profiling berbasis konsumen antara lain, Check-All-That-Apply (CATA), Rate-All- That-Apply (RATA), napping, dan projective mapping (Ares et al. 2009).

Adawiyah dan Yasa (2017) telah melakukan penelitian tentang profil sensori sediaan pemanis ideal dan pemanis komersial dengan metode Check-All-ThatApply (CATA) pada panelis diabetes dan non-diabetes, namun besar perbedaan intensitas atribut tidak dapat dinyatakan. Penggunaan metode Rate-All-That-Apply (RATA) dapat mengatasi kelemahan tersebut karena panelis memberikan nilai intensitas dari atribut tertentu, sehingga diharapkan hasil profil sensori sediaan pemanis dengan metode RATA lebih lengkap dan komprehensif dari penelitian sebelumnya. RATA merupakan uji yang dikembangkan dari metode CATA. Pada metode CATA, panelis menilai apakah suatu atribut sensori tertentu dapat dirasakan di dalam sampel dari daftar atribut yang sudah disediakan, sehingga menghasilkan suatu respon biner yaitu " 1 " untuk kehadiran dan "0" untuk ketidakhadiran suatu atribut tertentu (Ares et al. 2009). Karakteristik ini merupakan suatu kelemahan pada metode CATA, yaitu tidak dapat memberikan pengukuran pasti akan suatu intensitas sensori, sehingga menghambat diskriminasi suatu produk yang memiliki karakteristik sensori yang mirip, namun intensitasnya berbeda. 
Penggunaan metode RATA dapat mengatasi kelemahan tersebut karena panelis memberikan nilai intensitas dari atribut tertentu. Menurut Ares et al. (2014), respon RATA memberikan lebih banyak atribut sensori terdeteksi yang menyebabkan diskriminasi produk yang berbeda signifikan dibandingkan dengan CATA. Fibrianto dan Dwihindarti (2016) menggunakan metode RATA untuk mendapatkan gambaran profil jamu kunyit asam dan jamu sinom secara spesifik. Kelebihan dari metode RATA adalah adanya kesempatan yang diberikan kepada panelis untuk menggambarkan seberapa besar intensitas atribut sensori produk tersebut.

Selain identifikasi intensitas atribut sensori produk, diperlukan juga informasi terkait tingkat penerimaan produk untuk dapat mengidentifikasi atribut sensori yang berpengaruh dan menentukan penerimaan produk. Pengujian RATA umumnya disertai dengan uji rating hedonik (Ares et al. 2014; Jaeger dan Ares 2015; Meyners et al. 2016) untuk melihat kesukaan konsumen terhadap produk yang diuji. Oleh karena itu, pengujian intensitas atribut sering dilakukan bersamaan dengan uji penerimaan menggunakan rating hedonik agar profil sensori pada sediaan pemanis dapat dikorelasikan dengan penerimaan konsumen. Pengujian rating hedonik merupakan uji afektif yang bertujuan untuk menilai respon subjektif konsumen dalam hal penerimaan atau preferensi terhadap suatu produk. Respon subjektif konsumen dapat menunjukkan kesukaan konsumen terhadap sebuah produk secara aktual. Skala kategori yang biasa digunakan dalam uji rating bedonik adalah lima poin skala, tujuh poin skala, atau sembilan poin skala. Penilaian dilakukan konsumen terhadap sampel tanpa perlu membandingkan dengan sampel yang lain. Data dari uji rating hedonik dapat dianggap sebagai data interval dengan asumsi interval setiap poin sama (Meilgaard et al. 2016). Pengujian hedonik bersamaan dengan uji RATA kemungkinan besar tidak akan menimbulkan bias dalam data hedonik yang diperoleh (Jaeger dan Ares 2015).

Penelitian ini dilakukan bertujuan mempelajari profil sensori berbagai sediaan pemanis komersial berdasarkan persepsi konsumen, diabetes dan non-diabetes, dan tingkat intensitasnya dengan metode Rate-All-ThatApply (RATA), serta mengidentifikasi atribut yang dapat menentukan kesukaan konsumen dalam sediaan pemanis.

\section{BAHAN DAN METODE}

\section{Bahan}

Bahan utama yang digunakan pada penelitian ini adalah sukrosa dan enam sediaan pemanis komersial (selanjutnya disimbolkan dengan pemanis A, B, C, D, E, dan F). Bahan lain yang digunakan adalah air dan cracker krim unsalted atau tawar sebagai penetral.

Alat-alat yang digunakan pada penelitian ini adalah timbangan digital, gelas ukur plastik, botol plastik 800
$\mathrm{mL}$, gelas plastik kecil, kertas label, nampan, alat tulis, klip plastik, dan kertas kuesioner.

\section{Metode}

Penelitian ini dilakukan dalam empat tahap, yaitu diskusi kelompok terfokus atau Focus Group Discussion (FGD), pemilihan dan penetapan panelis, pengujian sensori, dan analisis data. Tahap pengujian sensori terdiri dari dua bagian, yaitu persiapan dan penyajian sampel serta pengambilan data.

\section{Diskusi kelompok terfokus/Focus Group Discussion (FGD)}

Focus Group Discussion (FGD) bertujuan mencari padanan istilah terbaik dalam menjelaskan atribut sensori pemanis kepada panelis tidak terlatih (konsumen). FGD dilakukan menggunakan delapan orang mahasiswa Ilmu dan Teknologi Pangan, IPB yang mewakili konsumen dan memiliki pemahaman memadai terhadap atribut sensori secara umum. Panelis mendiskusikan empat atribut sensori, sukrosa, dan enam sediaan pemanis. Empat atribut yang diuji adalah metallic, licorice, cooling, dan mouth drying untuk dicari padanan kata yang sesuai.Takaran penyajian untuk atribut tersebut dapat dilihat pada Tabel 1 .

\begin{tabular}{lll}
\multicolumn{2}{l}{ Tabel 1. Takaran penyajian referen } & \\
\hline \multicolumn{1}{c}{ Atribut } & \multicolumn{1}{c}{ Bahan } & \multicolumn{1}{c}{ Penyajian } \\
\hline Metallic & Suplemen zat besi & $\begin{array}{l}\text { Pengenceran } 10^{-8} \\
\text { Licorice }\end{array}$ \\
Kit & $\begin{array}{l}\text { Sesuai serving } \\
\text { suggestion }\end{array}$ \\
Cooling & Gula alkohol & $6 \%(\mathrm{~b} / \mathrm{v})$ \\
Mouth dryung & Gula alkohol & $6 \%(\mathrm{~b} / \mathrm{v})$ \\
\hline
\end{tabular}

Panelis diminta untuk menentukan istilah yang umum digunakan konsumen dalam menjelaskan atribut tersebut dan melakukan konsensus terhadap deskripsi setiap atribut. FGD dilakukan pada produk sebagai proses verifikasi atribut untuk selanjutnya dipakai di dalam daftar atribut pengujian Rate-All-That-Apply (RATA).

\section{Pemilihan dan penetapan panelis}

Panelis yang diinginkan pada penelitian ini mengacu pada target konsumen sediaan pemanis. Lokasi pengambilan data dilakukan di wilayah Jakarta, Bogor, Bekasi, Bandung, Tangerang, Serang, Cilegon. Pemilihan panelis dikategorikan berdasarkan riwayat kesehatan, yaitu (1) penderita diabetes, (2) non-diabetes dengan riwayat keturunan diabetes, dan (3) non-diabetes tanpa riwayat keturunan diabetes. Setiap kategori tersebut terdiri dari minimal 30 panelis, sehingga target sampel pada penelitian ini berjumlah 90 orang yang terdiri dari $51 \%$ perempuan dan $49 \%$ laki-laki. Rentang usia panelis adalah 20-65 tahun. Kuesioner pada tahap ini dirancang untuk menggali kriteria tersebut dan disebar melalui berbagai metode, antara lain secara online melalui google form yang dikirim via e-mail dan mendatangi langsung calon panelis untuk mengisi kertas kuesioner. 


\section{Persiapan dan penyajian sampel}

Sukrosa dilarutkan dalam air dengan konsentrasi $6.67 \%(\mathrm{~b} / \mathrm{v})$. Enam sediaan pemanis lainnya disajikan sesuai dengan serving suggestion yang tertera dalam label. Menurut BPOM (2014), pemanis sebagai sediaan pemanis hanya boleh dikemas dalam kemasan sekali pakai yang setara dengan 5-10 g sukrosa. Takaran penyajian sampel sediaan pemanis dapat dilihat pada Tabel 2.

Tabel 2. Takaran penyajian sampel sediaan pemanis sesuai label

\begin{tabular}{ccc}
\hline Sampel & Takaran Saji (gram) & Volume Air $(\mathbf{m L})$ \\
\hline A & 2.50 & 150 \\
B & 2.00 & 150 \\
C & 2.60 & 150 \\
D & 1.00 & 150 \\
E & 1.00 & 150 \\
F & 2.00 & 150 \\
\hline
\end{tabular}

Sampel disajikan kepada panelis satu persatu (monadic) dengan kode kombinasi 3 digit angka acak yang berbeda untuk setiap sampel. Penyajian dilengkapi dengan satu gelas air mineral $240 \mathrm{~mL}$ dan sekeping cracker krim. Urutan penyajian untuk setiap panelis diacak untuk menghindari bias dan mencegah diskusi. Sampel disajikan sebanyak $30 \mathrm{~mL}$ dalam cup plastik berukuran $90 \mathrm{~mL}$ pada suhu ruang. Sebelum mencicipi sampel, panelis melakukan pembilasan mulut dengan air mineral yang sudah disediakan. Panelis mencicipi masing-masing sampel dengan memberikan penilaian tanpa membandingkan antar sampel yang satu dengan yang lainnya. Panelis melakukan penetralan mulut dengan air mineral dan cracker krim saat pergantian sampel. Panelis yang menderita diabetes tidak disajikan sampel sukrosa.

Panelis diminta untuk mencicipi sampel dan melakukan uji hedonik dalam skala enam poin kesukaan (1=sangat tidak suka sampai $6=$ sangat suka). Selanjutnya, setiap panelis diminta untuk mencicipi sampel kembali dan menjawab pertanyaan RATA yang berisi sepuluh atribut sensori untuk menggambarkan profil sensori masing-masing sampel. Daftar atribut yang digunakan dapat dilihat pada Tabel 3. Panelis diminta untuk mengevaluasi dan menentukan atribut-atribut apa yang terdapat dalam sampel, kemudian memberikan tanda ceklis pada intensitas yang dirasakan pada atribut tertentu dalam skala lima poin (1=sangat lemah $5=$ sangat kuat). Apabila atribut tertentu tidak dirasakan pada sampel, maka atribut tersebut dikosongkan.

\section{Analisis data}

Analisis data RATA dilakukan secara terpisah pada setiap golongan panelis untuk membandingkan respon golongan panelis terhadap sediaan pemanis. Jenis analisis yang dilakukan adalah Principal Component Analysis (PCA), Non- parametric Friedman's test, dan Preference Mapping dengan perangkat lunak XLSTAT 2017.

Data intensitas RATA sediaan pemanis dianalisis dengan PCA dan Friedman's test. Analisis Friedman's test dilakukan untuk mengidentifikasi perbedaan yang signifikan antar sampel untuk setiap atribut sensori (Ares et al. 2014). Apabila didapatkan p-value kurang dari 5\%, maka dilakukan uji lanjut Duncan's. Selain itu dilakukan analisis Preference Mapping yang merupakan analisis untuk memahami hubungan antara karakteristik produk dengan preferensi konsumen dan mengerahui posisi produk pada target pasar dalam bentuk dua dimensi (Yenket et al. 2011).

\begin{tabular}{|c|c|c|}
\hline No & Atribut & Keterangan \\
\hline 1 & Sweet & Rasa manis \\
\hline 2 & Bitter & Rasa pahit \\
\hline 3 & Metallic & Rasa seperti logam \\
\hline 4 & $\begin{array}{l}\text { Body } \\
\text { thickness }\end{array}$ & Sensasi tebal atau kental di mulut \\
\hline 5 & Licorice & $\begin{array}{l}\text { Rasa seperti akar manis/obat batuk } \\
\text { yang terasa di pangkal lidah atau di } \\
\text { tenggorokan }\end{array}$ \\
\hline 6 & Cooling & Sensasi sejuk/dingin di mulut \\
\hline 7 & Mouth drying & Sensasi yang membuat kering di mulut \\
\hline 8 & $\begin{array}{l}\text { Metallic } \\
\text { aftertaste }\end{array}$ & $\begin{array}{l}\text { Aroma dan rasa seperti logam yang } \\
\text { tertinggal di mulut setelah ditelan }\end{array}$ \\
\hline 9 & $\begin{array}{l}\text { Sweet } \\
\text { aftertaste }\end{array}$ & $\begin{array}{l}\text { Rasa manis yang tertinggal di mulut } \\
\text { setelah ditelan }\end{array}$ \\
\hline 10 & $\begin{array}{l}\text { Bitter } \\
\text { aftertaste }\end{array}$ & $\begin{array}{l}\text { Rasa pahit yang tertinggal di mulut } \\
\text { setelah ditelan }\end{array}$ \\
\hline
\end{tabular}

\section{HASIL DAN PEMBAHASAN}

\section{Profil sensori sediaan pemanis}

Masing-masing atribut sensori antar sediaan pemanis dievaluasi dengan Friedman's test pada taraf signifikansi 5\%. Hasil dari Friedman's test dapat dilihat pada Tabel 4. Atribut yang memiliki perbedaan signifikan diuji lanjut dengan Duncan's (data tidak ditampilkan). Dari Tabel 4. dapat dilihat perbedaan signifikan teridentifikasi pada atribut yang berbeda-beda antar katagori panelis. Secara umum semua katagori panel tidak mampu membedakan perbedaan body thickness dan mouth drying antar sampel. Hasil yang serupa dilaporkan oleh Adawiyah dan Yasa (2017) menggunakan CATA, dimana seluruh atribut sensori pada produk sediaan pemanis yang sama memiliki perbedaan nyata kecuali sensasi kering di mulut (mouth drying) dan sensasi dingin (cooling). Dengan demikian pada metode RATA diperoleh atribut tambahan yang tidak dapat dibedakan oleh panelis yaitu atribut body thickness. Jika dilihat lebih lanjut dari rata-rata nilai intensitas yang diperoleh, intensitas body thickness dan mouth drying terdeteksi sangat lemah, masing-masing pada kisaran $(0.38-1.40)$ dan $(0.6-1.37)$. Rincian nilai intensitas dari atribut seperti yang dapat dilihat pada Tabel 5. merupakan keunggulan dari pemakaian metode RATA dimana dapat terlihat tingkat intensitas dari setiap atribut yang sebelumnya tidak diketahui pada metode CATA.

Panelis diabetes masih memiliki kemampuan dalam membedakan atribut sweet, bitter, licorice, sweet dan bitter aftertaste. Panelis non-diabetes tanpa riwayat keturunan diabetes menyatakan adanya perbedaan sweet, 
bitter, licorice, dan bitter aftertaste antar sampel yang diujikan. Sedangkan panel non-diabetes dengan keturunan menyatakan adanya perbedaan pada atribut yang paling banyak yaitu sweet, bitter, metallic, licorice, cooling, metallic, dan bitter aftertaste. Dengan demikian antar kelompok panel ada perbedaan persepsi dan interaksi antar atribut pada sampel pemanis yang berbeda.

Tabel 4. Nilai signifikansi ( $p$-value) dari hasil Friedman's test berbagai golongan panelis

\begin{tabular}{|c|c|c|c|}
\hline Atribut & Diabetes & $\begin{array}{c}\text { Non-diabetes } \\
\text { dengan Riwayat } \\
\text { Keturunan } \\
\text { Diabetes }\end{array}$ & $\begin{array}{c}\text { Non-diabetes } \\
\text { tanpa Riwayat } \\
\text { Keturunan }\end{array}$ \\
\hline Sweet & 0.000 & 0.000 & 0.000 \\
\hline Bitter & 0.016 & 0.000 & 0.000 \\
\hline Metallic & 0.653 & 0.022 & 0.348 \\
\hline $\begin{array}{l}\text { Body } \\
\text { thickness }\end{array}$ & 0.152 & 0.536 & 0.169 \\
\hline Licorice & 0.01 & 0.013 & 0.035 \\
\hline Cooling & 0.563 & 0.005 & 0.525 \\
\hline $\begin{array}{l}\text { Mouth } \\
\text { drying }\end{array}$ & 0.339 & 0.112 & 0.721 \\
\hline $\begin{array}{l}\text { Metallic } \\
\text { aftertaste }\end{array}$ & 0.075 & 0.004 & 0.192 \\
\hline $\begin{array}{l}\text { Sweet } \\
\text { aftertaste }\end{array}$ & 0.009 & 0.004 & 0.120 \\
\hline Bitter & 0.012 & 0.012 & 0.000 \\
\hline
\end{tabular}

Keterangan: Tulisan angka dalam cetakan tebal menunjukkan adanya perbedaan signifikan antar sampel pemanis pada masingmasing atribut dengan $\alpha 5 \%$.

Adanya perbedaan persepsi dan interaksi antar atribut yang berbeda pada setiap golongan panelis lebih jelas lagi dapat dilihat dari plot grafik Principal Component Analysis (PCA) seperti yang dapat dilihat pada Gambar 1. Menurut panelis diabetes, produk A memiliki ciri khas sweet, cooling, sweet aftertaste, licorice, body thickness, dan mouth drying. Produk B, walaupun tidak memiliki atribut di dalam kuadrannya, memiliki sifat yang mirip dengan A dilihat dari sudut vektor sediaan pemanis dan atributnya. Sudut vektor yang kecil menunjukkan produk B memiliki sifat sweet cooling, dan sweet aftertaste. Produk C dan F memiliki ciri khas metallic, bitter, bitter aftertaste, dan metallic aftertaste. Produk D dan E tidak memiliki ciri khas yang dominan (Gambar 1a). Terlihat pada Gambar 1b dan Gambar 1c, panelis non-diabetes dengan riwayat keturunan diabetes memiliki perbedaan persepsi. Pada panelis non-diabetes dengan riwayat keturunan, produk F memiliki ciri khas berupa body thickness, sweet, sweet aftertaste, dan licorice. Produk A, B, dan sukrosa memiliki sifat sweet dan body thickness dilihat dari kedekatannya dengan atribut. Produk C lebih kaya atribut dengan mouth drying, bitter, bitter aftertase, metallic aftertaste, cooling, dan metallic. Sedangkan pada panelis non-diabetes tanpa riwayat keturunan diabetes, produk A, B, dan sukrosa berada dalam satu kuadran yang menunjukkan kemiripan antar produk dengan ciri khas sweet aftertaste dan cooling. Produk $\mathrm{C}$ memiliki ciri licorice, sweet, body thickness, dan mouth drying. Produk F memiliki ciri khas bitter, bitter aftertaste, metallic aftertaste, dan metallic. Produk D dan E tidak memiliki ciri khas yang dominan.

Perbedaan sensitivitas dan persepsi panelis juga dapat dijelaskan dari pola konsumsi makanan yang berbeda diantara golongan tersebut, dimana penderita diabetes menjauhi makanan yang manis karena sering diasosiasikan dengan gula yang dapat meningkatkan kadar gula darah (Wasalathanthri et al. 2014). Selain itu, konsumsi obat secara rutin dapat memberikan pengaruh kepada persepsi rasa seseorang dengan cara mengurangi fungsi indra atau membuat respon menyimpang dengan bias dan ilusi rasa.

Tabel 5. Intensitas atribut sensori sediaan pemanis pada berbagai golongan panelis dari hasil uji lanjut Duncan

\begin{tabular}{|c|c|c|c|c|c|c|c|c|c|c|c|}
\hline \multirow[b]{2}{*}{ Golongan } & \multirow[b]{2}{*}{ Sampel } & \multicolumn{10}{|c|}{ Atribut Sensori } \\
\hline & & Sweet & Bitter & Metallic & $\begin{array}{c}\text { Body } \\
\text { Thickness }\end{array}$ & Licorice & Cooling & $\begin{array}{l}\text { Mouth } \\
\text { Drying }\end{array}$ & $\begin{array}{c}\text { Metallic } \\
\text { Aftertaste }\end{array}$ & $\begin{array}{c}\text { Sweet } \\
\text { Aftertaste }\end{array}$ & $\begin{array}{c}\text { Bitter } \\
\text { Aftertaste }\end{array}$ \\
\hline \multirow{6}{*}{ Diabetes } & A & $3.77^{d}$ & $0.50^{\mathrm{a}}$ & 0.63 & 1.13 & $1.53^{b}$ & 1.27 & 0.90 & 0.50 & $2.33^{c}$ & $0.37^{a}$ \\
\hline & B & $3.07^{c}$ & $0.83^{a b c}$ & 0.63 & 0.77 & $1.13^{\mathrm{ab}}$ & 1.27 & 0.77 & 0.43 & $1.60^{\mathrm{b}}$ & $0.53^{\mathrm{ab}}$ \\
\hline & C & $2.67^{a}$ & $1.13^{\mathrm{bc}}$ & 0.80 & 1.03 & $1.27^{\mathrm{ab}}$ & 1.10 & 0.67 & 0.53 & $1.60^{\mathrm{ab}}$ & $0.80^{\mathrm{ab}}$ \\
\hline & D & $2.00^{\mathrm{b}}$ & $0.77^{a b c}$ & 1.03 & 0.90 & $0.70^{a}$ & 0.70 & 0.60 & 0.53 & $1.20^{\mathrm{a}}$ & $0.47^{a}$ \\
\hline & $E$ & $2.50^{\mathrm{b}}$ & $0.73^{a b}$ & 0.67 & 0.83 & $0.90^{\mathrm{a}}$ & 0.90 & 0.67 & 0.40 & $1.40^{\mathrm{ab}}$ & $0.50^{\mathrm{ab}}$ \\
\hline & $\mathrm{F}$ & $2.70^{\mathrm{bc}}$ & $1.30^{c}$ & 1.07 & 1.20 & $1.70^{\mathrm{b}}$ & 1.70 & 1.30 & 0.90 & $1.93^{b c}$ & $0.93^{b}$ \\
\hline & A & $3.50^{\mathrm{b}}$ & $0.53^{a}$ & $0.73^{a b}$ & 1.27 & $1.93^{\mathrm{abc}}$ & 1.03 & 1.33 & 0.57 & $2.50^{a b c}$ & $0.67^{a}$ \\
\hline Non & B & $3.40^{\mathrm{b}}$ & $0.47^{\mathrm{a}}$ & $0.63^{\mathrm{ab}}$ & 1.40 & $1.47^{\mathrm{a}}$ & $1.47^{\mathrm{ab}}$ & 1.20 & $0.57^{a b}$ & $2.34^{\mathrm{abc}}$ & $0.60^{\mathrm{a}}$ \\
\hline Diabetes & C & $3.63^{b}$ & $1.37^{c}$ & $1.07^{b}$ & 1.13 & $2.13^{b c}$ & $2.13^{\mathrm{ab}}$ & 1.63 & $0.97^{\mathrm{ab}}$ & $2.90^{c}$ & $1.47^{b}$ \\
\hline Riwayat & D & $2.70^{\mathrm{a}}$ & $0.47^{\mathrm{a}}$ & $0.77^{\mathrm{ab}}$ & 0.38 & $1.47^{\mathrm{a}}$ & $1.47^{b}$ & 0.93 & $0.43^{\mathrm{b}}$ & $1.97^{\mathrm{a}}$ & $0.80^{\mathrm{a}}$ \\
\hline Keturunan & E & $2.67^{a}$ & $0.77^{\mathrm{ab}}$ & $0.80^{\mathrm{ab}}$ & 1.00 & $1.70^{\mathrm{ab}}$ & $1.70^{\mathrm{a}}$ & 1.20 & $0.87^{a}$ & $2.03^{\mathrm{a}}$ & $0.63^{\mathrm{a}}$ \\
\hline \multirow[t]{2}{*}{ Diabetes } & $\mathrm{F}$ & $3.33^{b}$ & $1.03^{\mathrm{bc}}$ & $0.67^{\mathrm{ab}}$ & 1.40 & $2.37^{\mathrm{c}}$ & $2.37^{b}$ & 1.17 & $1.00^{\mathrm{ab}}$ & $2.70^{b c}$ & $1.10^{\mathrm{b}}$ \\
\hline & Sukrosa & $3.80^{b}$ & $0.37^{\mathrm{a}}$ & $0.33^{\mathrm{a}}$ & 1.20 & $1.47^{\mathrm{a}}$ & $1.47^{b}$ & 0.97 & $0.37^{b}$ & $2.17^{\mathrm{ab}}$ & $0.67^{a}$ \\
\hline \multirow{7}{*}{$\begin{array}{l}\text { Non } \\
\text { Diabetes } \\
\text { tanpa } \\
\text { Riwayat } \\
\text { Keturunan } \\
\text { Diabetes }\end{array}$} & A & $3.40^{c}$ & $0.77^{\mathrm{ab}}$ & 0.40 & 0.97 & $1.83^{b}$ & $1.83^{\mathrm{ab}}$ & 1.27 & $0.33^{\mathrm{a}}$ & 2.43 & $0.67^{a}$ \\
\hline & B & $3.03^{b c}$ & $0.43^{\mathrm{a}}$ & 0.37 & 1.10 & $1.37^{\mathrm{ab}}$ & 1.37 & 1.13 & 0.50 & 2.03 & $0.63^{\mathrm{a}}$ \\
\hline & C & $3.27^{c}$ & $1.67^{\mathrm{c}}$ & 0.60 & 1.13 & $1.60^{a b}$ & 1.60 & 1.37 & 0.83 & 1.77 & $1.77^{\mathrm{b}}$ \\
\hline & D & $2.53^{\mathrm{ab}}$ & $1.00^{\mathrm{bc}}$ & 0.37 & 0.67 & $1.50^{\mathrm{ab}}$ & 1.50 & 0.90 & 0.43 & 1,80 & $0.87^{a}$ \\
\hline & $E$ & $2.37^{a}$ & $0.57^{a b}$ & 0.27 & 0.77 & $1.10^{\mathrm{a}}$ & 1.10 & 1.03 & 0.37 & 1.63 & $0.63^{\mathrm{a}}$ \\
\hline & $\mathrm{F}$ & $3.13^{c}$ & $1.53^{c}$ & 0.83 & 0.87 & $1.13^{\mathrm{a}}$ & 1.13 & 1.27 & 0.70 & 1.67 & $1.23^{\mathrm{ab}}$ \\
\hline & Sukrosa & $3.37^{c}$ & $0.40^{\mathrm{a}}$ & 0.33 & 0.80 & $1.47^{\mathrm{ab}}$ & 1.47 & 1.07 & 0.57 & 1.63 & $0.67^{\mathrm{a}}$ \\
\hline
\end{tabular}

Keterangan: Huruf superskrip yang berbeda menunjukkan perbedaan nyata pada taraf $5 \%$. Hasil friedman yang tidak berbeda, tidak dilanjutkan dengan uj Duncan. 
(a)

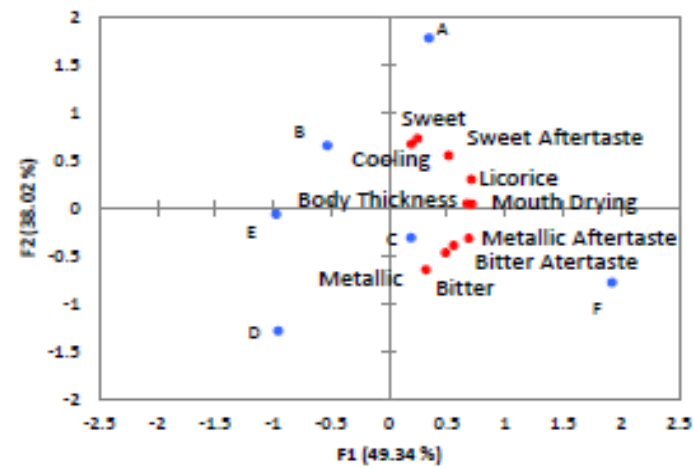

(b)

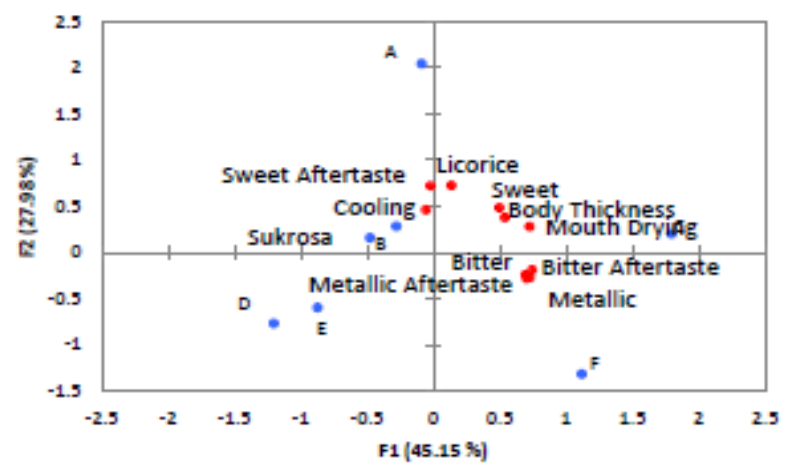

(c)

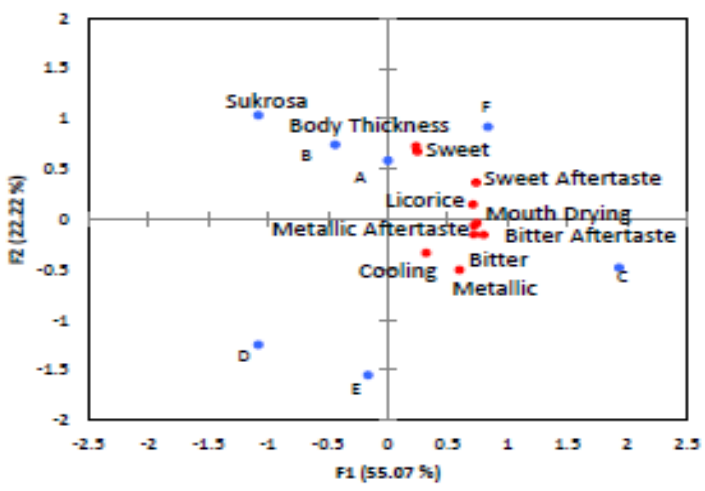

Gambar 1. Representasi profil sensori sediaan pemanis berdasarkan persepsi (a) panelis diabetes, (b) panelis nondiabetes dengan riwayat keturunan, dan (c) panelis non-diabetes tanpa riwayat keturunan

\section{Peta kesukaan panelis terhadap sediaan pemanis}

Peta kesukaan, atau preference mapping, merupakan hasil analisis berupa contour plot yang terdiri dari beberapa warna untuk menggambarkan persentase panelis memberikan nilai kesukaan diatas rata-rata pada suatu produk. Warna merah menunjukkan jumlah panelis dengan kesukaan di atas rata-rata yang tinggi, yaitu $80 \%-100 \%$ dan menurun dengan menjadi kuning $(60 \%-$ $80 \%)$, hijau (40-60\%), biru muda (20\%-40\%), dan biru tua (0\%-20\%). Selain itu, dengan melakukan overlay pada contour plot dengan PCA, maka dapat diketahui atribut yang dapat berkorelasi dengan kesukaan panelis dan sediaan pemanis yang memiliki ciri khas tersebut untuk dilakukan pengembangan produk.

Berdasarkan Gambar 2a, terlihat kecederungan kesukaan panelis diabetes, yaitu produk $\mathrm{A}, \mathrm{B}$, dan $\mathrm{E}$ yang berada dalam wilayah berwarna kuning. Hal ini menunjukkan produk tersebut mendapatkan 60\%-80\% kesukaan di atas rata-rata. Produk B dan E mendekati wilayah berwarna merah yang memiliki kesukaan di atas rata-rata mencapai $80 \%-100 \%$ panelis. Produk C dan D berada di wilayah biru muda dengan nilai kesukaan di atas rata-rata diantara $20-40 \%$ panelis, sedangkan produk $\mathrm{F}$ hanya mendapatkan nilai kesukaan di atas ratarata $0 \%-20 \%$ panelis. Panelis diabetes tidak memiliki atribut yang diinginkan dalam preferensi tinggi dilihat dari atribut yang tidak terletak pada wilayah merah, namun panelis dapat menentukan atribut yang tidak disukai dengan pasti pada sediaan pemanis dengan banyaknya jumlah atribut yang terletak pada wilayah berwarna biru muda dan biru tua. Atribut yang cukup disukai adalah sweet, cooling, dan sweet aftertaste yang terletak pada wilayah berwarna kuning. Atribut yang terletak pada wilayah berwarna biru muda adalah licorice, body thickness, mouth drying, dan metallic. Atribut yang sangat tidak disukai pada wilayah biru tua adalah bitter, bitter aftertaste, dan metallic aftertaste. Berdasarkan informasi tersebut, Produk A dan B yang memiliki atribut sweet, cooling, dan sweet aftertaste memiliki potensi untuk mendapatkan kesukaan di atas rata-rata lebih banyak lagi. Produk $\mathrm{C}$ dan $\mathrm{F}$ dapat lebih disukai dengan menutupi atribut yang tidak disukai, yaitu metallic, bitter, bitter aftertaste, dan metallic aftertaste. Apabila produk $\mathrm{D}$ dan $\mathrm{E}$ melakukan reformulasi dan meningkatkan atribut sweet, cooling, dan sweet aftertaste, kedua sediaan pemanis tersebut dapat meningkatkan kesukaan dari panelis diabetes.

Terlihat pada Gambar 2b, panelis non-diabetes dengan riwayat keturunan diabetes memiliki preferensi yang berbeda dengan panelis diabetes. Pemanis yang mendapatkan nilai kesukaan di atas rata-rata paling tinggi adalah sukrosa dan B. Produk A dan D berada di wilayah berwarna kuning, $\mathrm{E}$ dan $\mathrm{F}$ berada di wilayah berwarna biru muda, dan $\mathrm{C}$ berada pada wilayah berwarna biru tua. Sama halnya dengan panelis diabetes, panelis non-diabetes dengan riwayat keturunan diabetes tidak memiliki atribut yang secara pasti disukai, namun mengetahui atribut yang tidak diinginkan pada sediaan pemanis. Atribut yang cukup disukai adalah sweet dan body thickness pada wilayah berwarna kuning. Atribut yang tidak disukai adalah sweet aftertaste dan licorice pada wilayah berwarna biru muda, sedangkan atribut yang paling tidak disukai adalah mouth drying, bitter aftertaste, metallic aftertaste, bitter, cooling, dan metallic. Seperti produk A, B memiliki potensi untuk disukai oleh $80 \%-100 \%$ panelis di atas rata-rata karena 
sudah memiliki atribut body thickness dan sweet yang cukup disukai panelis non-diabetes dengan riwayat keturunan diabetes. Produk C dan F perlu menutup atribut yang tidak disukai dan meningkatkan atribut yang disukai untuk merebut pasar dari konsumen nondiabetes dengan riwayat keturunan diabetes. Apabila produk D dan E melakukan reformulasi dan meningkatkan atribut sweet dan body thicnkess, kedua sediaan pemanis tersebut dapat meningkatkan kesukaan dari panelis non-diabetes dengan riwayat keturunan diabetes.

Dari Gambar 2c, dapat diketahui bahwa panelis nondiabetes tanpa riwayat keturunan diabetes memberikan nilai kesukaan di atas rata-rata tertinggi pada sukrosa, D, dan E. Produk A dan B berada pada wilayah berwarna kuning, $\mathrm{F}$ berada pada wilayah berwarna biru muda, dan C berada pada wilayah berwarna biru tua. Produk B mendekati wilayah berwarna merah dan merupakan sediaan pemanis yang menyerupai sukrosa dan berpotensi untuk mencapai kesukaan di atas rata-rata untuk panelis non-diabetes tanpa riwayat keturunan diabetes.

Sama halnya dengan kedua golongan panelis lainnya, panelis non-diabetes tanpa riwayat keturunan diabetes tidak memiliki atribut yang secara pasti disukai, namun mengetahui atribut yang tidak diinginkan pada sediaan pemanis. Atribut yang cukup disukai adalah sweet aftertaste, cooling, dan licorice. Atribut yang agak tidak disukai adalah sweet, bitter, metallic aftertaste, dan metallic. Atribut yang tidak disukai adalah body thickness, mouth drying, dan bitter aftertaste. Produk A dan B berpotensi untuk disukai di atas rata-rata karena memiliki atribut yang cukup disukai yaitu sweet aftertaste, cooling, dan licorice. Produk $\mathrm{C}$ dan $\mathrm{F}$ perlu menutup atribut yang tidak disukai dan meningkatkan atribut yang disukai untuk merebut pasar dari konsumen non-diabetes tanpa riwayat keturunan diabetes.

Berdasarkan peta kesukaan dari setiap golongan, konsumen belum bisa mendefinisikan atribut yang disukai secara pasti pada sediaan pemanis. Hal ini terlihat dengan ketiadaan atribut pada wilayah berwarna merah. Akan tetapi, secara umum konsumen sudah dapat menentukan atribut yang tidak diinginkan dalam sediaan pemanis, yaitu bitter, bitter aftertaste, metallic, metallic aftertaste, dan mouth drying. $\mathrm{C}$ dan $\mathrm{F}$ dapat lebih disukai dengan menutupi atribut-atribut tersebut.

Profil Sensori dari pemanis A dan B lebih kaya daripada D dan E, akan tetapi hal tersebut tidak sepenuhnya menentukan tingkat kesukaan sediaan pemanis dari konsumen. Artinya, konsumen menunjukkan preferensi terhadap sediaan pemanis dengan meninjau ketiaadaan atribut yang tidak disukai daripada dominasi atribut yang disukai. Hal ini terjadi karena sukrosa merupakan pemanis yang secara umum dipakai oleh masyarakat, sehingga rasa dari sediaan pemanis dibandingkan dengan sukrosa. Sukrosa memiliki karakteristik manis yang clean dan memiliki rasa pahit dan non-sweet aftertaste yang rendah (Sediva et al. 2006). Non-nutritive sweetener seringkali memiliki atribut lain yang membuatnya berbeda dengan sukrosa. Oleh karena itu, penggunaan beberapa jenis pemanis diperlukan untuk menciptakan ulang rasa yang semirip mungkin dengan sukrosa (Deis 2006). Hal ini menyebabkan D dan $\mathrm{E}$ yang tidak memiliki ciri khas tertentu menjadi lebih disukai. Selain itu, terdapat kemungkinan adanya atribut sediaan pemanis yang belum tercakup dalam penelitian ini dalam $\mathrm{D}$ dan $\mathrm{E}$ yang disukai dan menjadi ciri khasnya.

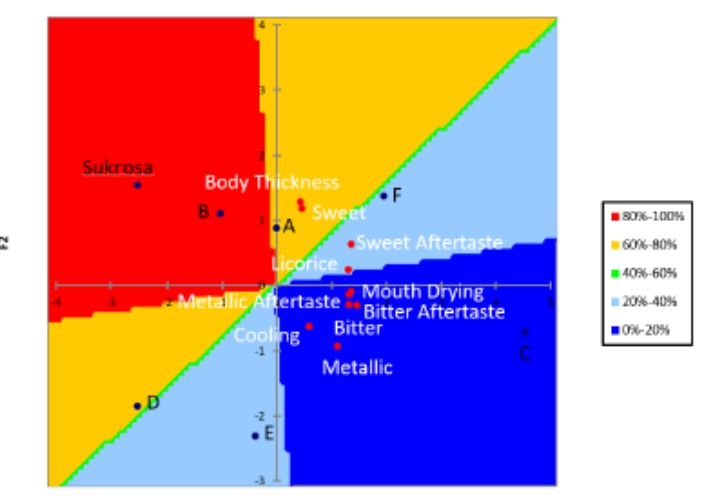

(a)

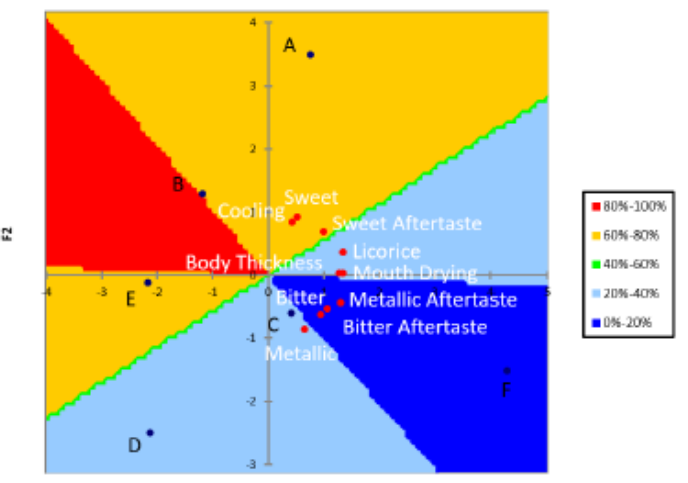

(b)

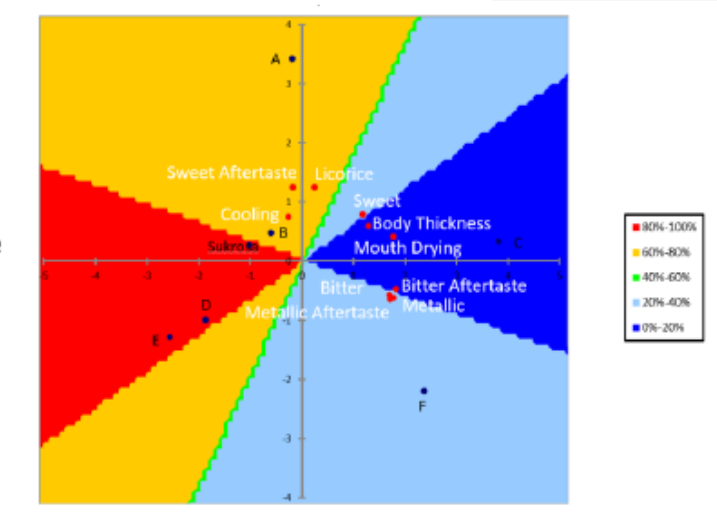

Gambar 2. Peta kesukaan sediaan pemanis berdasarkan p̣ersepsi (a) panelis diabetes, (b) panelis non-diabetes dengan riwayat keturunan diabetes, dan (c) panelis non-diabetes tanpa riwayat keturunan diabetes. 


\section{KESIMPULAN}

Persepsi panelis diabetes, non-diabetes dengan riwayat keturunan diabetes, dan non-diabetes tanpa riwayat keturunan diabetes terhadap sediaan pemanis berbeda-beda. Produk A identik dengan atribut cooling, sweet aftertaste, sweet, body thickness, licorice, dan mouth drying. Produk $\mathrm{C}$ dan $\mathrm{F}$ identik dengan atribut metallic aftertaste, bitter aftertaste, bitter, dan metallic. Produk D dan E tidak memiliki atribut yang dominan. Panelis diabetes memberikan nilai kesukaan diatas ratarata terbanyak pada produk B, A, dan E. Panelis nondiabetes dengan riwayat keturunan diabetes memberikan nilai kesukaan diatas rata-rata terbanyak pada produk B. Panelis non-diabetes tanpa riwayat keturunan diabetes memberikan nilai kesukaan diatas rata-rata terbanyak pada produk E dan D. Secara keseluruhan, konsumen belum bisa mendefinisikan atribut yang disukai, namun sudah dapat menentukan atribut yang tidak diinginkan dalam sediaan pemanis, yaitu bitter, bitter aftertaste, metallic, metallic aftertaste, dan mouth drying. Pada pembuatan sediaan pemanis, diperlukan kombinasi penggunaan pemanis yang memiliki atribut sweet dan sweet aftertaste yang panjang untuk menutupi atribut non-sweet yang tidak disukai.

\section{UCAPAN TERIMA KASIH}

Ucapan terimakasih ditujukan kepada PT. Nutrifood Indonesia, Ciawi, Jawa Barat yang telah memfasilitasi penelitian ini.

\section{DAFTAR PUSTAKA}

Adawiyah DR, Yasa KI. 2017. Evaluasi profil sensori sediaan pemanis komersial menggunakan metode Chek-All-That-Apply (CATA). J Mutu Pangan 4(1): 23-29.

[AMI] Applied Market Information. 2001. Market share of non-caloric sweeteners by segments. AMI Business Consulting Analysis.

Ares G, Bruzzone F, Vidal L, Cadena RS, Gimenez A, Pineau B, Hunter DC, Paisley AG, Jaeger SR. 2014. Evaluation of a rating-based variant check-all- thatapply questions: Rate-All-That-Apply (RATA). Food Qual Preferences 36(2014): 87-95. DOI: 10.1016/j.foodqual.2014.03.006.

Ares G, Deliza R, Barreiro C, Gimenez A, Gambaro A. 2009. Comparison of two sensory profiling techniques based on consumer perception. Food Qual Preference 21(2010): 417-426. DOI: 10.10 16/j.foodqual.2009.10.006.
Ares G, Varela P, Rado G, Gimenez A. 2011. Are consumer profiling techniques equivalent for some product categories? The case of orange-flavoured powdered drinks. Int J Food Sci Technol 46(1): 1600-1608. DOI: $10.1111 / \mathrm{j} .13652621 .2011 .02657$. $\mathrm{x}$.

[BPOM] Badan Pengawas Obat dan Makanan. 2014. Peraturan Kepala Badan Pengawas Obat dan Makanan Republik IndonesiaNomor 4 Tahun 2014 tentang Batas Maksimum Penggunaan Bahan Tambahan Pangan Pemanis. Jakarta (ID): BPOM.

Deis RC. 2006. Customizing sweetness profiles. Food Product Design 15(11):1-5.

Fibrianto K, Dwihindarti M. 2016. Profiling atribut jamu kunyit asam dan jamu sinom dengan metode rata (rate-all-that-apply) pada beberapa kota di Jawa Timur. J Rekapangan 10(1): 15-21.

Jaeger SR, Ares G. 2015. RATA questions are not likely to bias hedonic scores. Food Qual Preference 44(2015): 157-161. DOI: 10.1016/j.foodqual.2015. 04.011 .

Meilgaard MC, Civile GV, Carr BT. 2016. Sensory Evaluation Technique. CRC Press, New York, USA.

Menteri Kesehatan Republik Indonesia. 2012. Peraturan Menteri Kesehatan Republik Indonesia No: 033 Tahun 2012 tentang Bahan Tambahan Pangan. Jakarta (ID): Menteri Kesehatan.

Meyners M, Jaeger SR, Ares G. 2016. On the analysis of Rate-All-That-Apply (RATA) data. Food Qual Preference 49(2016): 1-10. DOI: 10.1016/j.food qual.2015.11.003.

Lawless HT, Heymann H. 2010. Sensory Evaluation of Food: Principles and Practices. New York (US): Springer. DOI: 10.1007/978-1-4419-6488-5_3.

Sediva A, Panovska Z, Pokorny J. 2006. Sensory profiles of sweeteners in aqueous solutions. Czech J Food Science 24(6): 283-287. DOI: 10.17221/3326CJFS.

Wansink B. 2003. Response to "Measuring consumer responses to food product" sensory test that predict consumer acceptance. Food Qual Preference 14: 2326. DOI: 10.1016/S0950-3293(02)00035-6.

Wasalathanthri S, Hettiarachchi P, Prathapan S. 2014. Sweet taste sensitivity in pre- diabetics, diabetics, and normoglycemic controls: a comparative cross sectional study. BMC Endocrine Disorders 14, 67(2014) DOI: 10.1186/1472-6823-14-67.

JMP-04-20-06-Naskah diterima untuk ditelaah pada 4 Maret 2020. Revis makalah disetujui untuk dipublikasi pada 1 April 2020. Versi Online: http://journal.ipb.ac.id/index.php/jmpi 